\title{
Phytochemical composition, antiparasitic and $\alpha$-glucosidase inhibition activities from Pelliciera rhizophorae
}

\author{
Dioxelis López ${ }^{1,2}$, Lilia Cherigo ${ }^{3}$, Carmenza Spadafora ${ }^{4}$, Marco A. Loza-Mejía ${ }^{5}$ and Sergio Martínez-Luis ${ }^{\text {* }}$
}

\begin{abstract}
Background: Panama has an extensive mangrove area and it is one of the countries with the highest biodiversity in America. Mangroves are widely used in traditional medicine, nevertheless, there are very few studies that validates their medicinal properties in America. Given the urgent need for therapeutic options to treat several diseases of public health importance, mangrove ecosystem could be an interesting source of new bioactive molecules. This study was designed to evaluate the potential of Pelliciera rhizophorae as a source of bioactive compounds.

Results: The present investigation was undertaken to explore the possible antiparasitic potential and $\alpha$-glucosidase inhibition by compounds derived from the Panamanian mangrove Pelliciera rhizophorae. Bioassay-guided fractionation of the crude extract led to the isolation of ten chemical compounds: $\alpha$-amyrine (1), $\beta$-amyrine (2), ursolic acid (3), oleanolic acid (4), betulinic acid (5), brugierol (6) iso-brugierol (7), kaempferol (8), quercetin (9), and quercetrin (10). The structures of these compounds were established by spectroscopic analyses including APCI-HR-MS and NMR. Compounds $\mathbf{4}\left(\mathrm{IC}_{50}=5.3 \mu \mathrm{M}\right), \mathbf{8}\left(\mathrm{I} \mathrm{C}_{50}=22.9 \mu \mathrm{M}\right)$ and $\mathbf{1 0}\left(\mathrm{I} \mathrm{C}_{50}=3.4 \mu \mathrm{M}\right)$ showed selective antiparasitic activity against Leishmania donovani, while compounds $\mathbf{1}\left(\mathrm{IC}_{50}=19.0 \mu \mathrm{M}\right)$ and $\mathbf{5}\left(\mathrm{IC}_{50}=18.0 \mu \mathrm{M}\right)$ exhibited selectivity against Tripanosoma cruzi and Plasmodium falciparum, respectively. Moreover, compounds $\mathbf{1}-\mathbf{5}$ inhibited $\alpha$-glucosidase enzyme in a concentration-dependent manner with $\mathrm{IC}_{50}$ values of $1.45,0.02,1.08,0.98$ and $2.37 \mu \mathrm{M}$, respectively. Their inhibitory activity was higher than that of antidiabetic drug acarbose $\left(I C_{50} 217.7 \mu \mathrm{M}\right)$, used as a positive control. Kinetic analysis established that the five compounds acted as competitive inhibitors. Docking analysis predicted that all triterpenes bind at the same site that acarbose in the human intestinal $\alpha$-glucosidase (PDB: 3TOP).

Conclusions: Three groups of compounds were isolated in this study (triterpenes, flavonols and dithiolanes). Triterpenes and flavones showed activity in at least one bioassay (antiparasitic or $\alpha$-glucosidase). In addition, only the pentacyclic triterpenes exhibited a competitive type of inhibition against $\alpha$-glucosidase.
\end{abstract}

Keywords: $\alpha$-Glucosidase, Pelliciera rhizophorae, Triterpenes, Mangroves, Diabetes

\section{Background}

Present world is a place of high mortality rates mainly due to severe poverty. High levels of poverty results in malnutrition, overcrowding, bad sanitation and polluted water. These conditions lead to a fertile environment for parasitic diseases and diabetes. A parasitic infection is

\footnotetext{
*Correspondence: smartinez@indicasat.org.pa

${ }^{1}$ Center for Drug Discovery and Biodiversity, Institute for Scientific Research and Technology Services (INDICASAT), Clayton, P.O.

Box 0843-01103, Panama City, Republic of Panama

Full list of author information is available at the end of the article
}

one of the leading causes of chronic human diseases in most tropical countries. The parasites, including protozoa and helminthes, infect billions of people and can result in blindness, disfigurement, or even death. Efforts to develop vaccines against these pathogens have been prevented by the difficulty of cultivation of parasites in the laboratory, the complexity of their multicellular organization and many species have been developing impressive antigenic variability. At the same time, most treatments involve highly toxic drugs and parasites has greatly increased the drug-resistant and finally, the 
chemotherapeutic agents used in infected patients have lacked effectiveness [1-3].

Another major cause of mortality is Diabetes mellitus (DM), it was responsible for about 1.5 million deaths in 2012. According to World Health Organization (WHO) forecasts, DM will be the 7th leading cause of death in 2030, and its prevalence has shown to be higher in low and middle-income countries. This disease is known for allowing high sugar levels in human blood, either because insulin production is inadequate or because the body's cells do not respond properly to insulin, or both. Patients with high blood sugar will typically present many fatal disorders in different organs, including hyperosmolar hyperglycemic nonketotic syndrome, feet and skin complications, amputations, hypertension, retinopathy, neuropathy and diabetic nephropathy $[4,5]$. Thus, there is an urgent need to search for novel drugs from several sources, including natural products, to fight global health problems posed by parasitic infections and DM.

In the western hemisphere, mangroves are a natural source that has been poorly explored for biomedical potential. Mangroves are a group of halophytes plants that are developed in the tropical or subtropical areas, functioning as a bridge between the marine and terrestrial habitats. Mangroves are highly adapted to their environment and they are able to deal with many physical stress factors such as strong variation in moisture and salt concentrations, changing tides, and biological stressing factors produced by abundant herbivorous insects [6]. Currently, mangrove plants and their extracts are mainly used by dwellers for medicinal use, especially for the treatment skin infections, tuberculosis, skin wounds, diarrhea, and other uses such as insecticides and piscicides [6-8]. Mangroves are a good source of secondary metabolites such as alkaloids, steroids, flavonoids, saponins, tannins, and triterpenes. Chemical studies using mangrove plants have led to the isolation of over 200 bioactive compounds $[8,9]$.

Panama has an extensive mangrove area and it is one of the countries with the highest biodiversity in America [6]. Mangroves are widely used in traditional medicine, nevertheless, there are very few studies that validates their medicinal properties in America. Given the urgent need for therapeutic options to treat several diseases of public health importance, mangrove ecosystem could be an interesting source of new bioactive molecules. This study was designed to evaluate the potential of Pelliciera rhizophorae as a source of bioactive compounds. Here we report the isolation, identification and bioactivity against three parasites (Leishmania donovani, Plasmodium falciparum and Trypanosoma cruzi) and the modulation of $\alpha$-glucosidase function of compounds produced by this plant, which is endemic mangrove from Central America.

\section{Results}

\section{Chemical study}

Pelliciera rhizophorae (Pellicieraceae) is an endemic mangrove plant from the Central American coasts. Mangrove leaves were collected in the protected mangrove area of Chame Bay, Panama. In the initial screening (against $P$. falciparum, T. cruzi and L. donovani), the crude extract did not present antiparasitic activity but it showed good inhibition against $\alpha$-glucosidase enzyme ( $82 \%$ of inhibition). Following the protocols of our laboratory we performed a primary fractionation by open column chromatography to afford 37 fractions. All fractions were submitted for bioactivity testing, resulting in fractions IX (70 \% growth inhibition (GI) against T. cruzi), FXIII (83 \% GI against $L$. donovani and $69 \% \mathrm{GI}$ against $P$. falciparum), FXXVIII ( $80 \%$ GI against L. donovani, 73 \% GI against $P$. falciparum and $67 \%$ GI against $T$. cruzi), and FXXXIII (75 \% GI against $L$. donovani) having antiparasitic properties and fractions IX (86 \%), FXIII (93\%), and FXXXIII (84 \%) showed inhibition of $\alpha$-glucosidase activity at a concentrations of $10 \mu \mathrm{g} / \mathrm{mL}$ for parasites and $6.25 \mu \mathrm{g} / \mathrm{mL}$ for $\alpha$-glucosidase. Bioassay-guided fractionation of the active fractions yielded compounds $\alpha$-amyrine (1), $\beta$-amyrine (2), ursolic acid (3), oleanolic acid (4), betulinic acid (5), brugierol (6), iso-brugierol (7), kaempferol (8), quercetin (9) and quercetrin (10), which were established by spectroscopic analyses including APCI-HR-MS and NMR $\left({ }^{1} \mathrm{H},{ }^{13} \mathrm{C}\right.$, DEPT 135, DEPT 90, COSY, NOESY, $\mathrm{HMBC}$ and HMQC). The structures (Fig. 1) were corroborated by comparing the spectroscopic and spectrometric data with those previously reported [10-18]. Even though the isolated compounds are quite common compounds, and are found in many other plant species, it should be emphasized that this is the first report about the occurrence of triterpenes, flavonoids and dithiolanes in the genus Pelliciera. Therefore, this plant represents a new source of this type of bioactive substances, which in several studies they have shown beneficial properties for human health.

\section{Antiparasitic activity}

Compounds 3, 4, 8, 9 and 10 displayed biological activity against the amastigotes of $L$. donovani (Table 1 ). This result was expected mainly because in previous reports ursolic acid showed activity against the promastigotes of L. donovani [19], oleanolic acid inhibited the promastigotes of $L$. braziliensis and $L$. chagasi [20], while quercetin, kaempferol and quercetrin displayed a leishmanicidal effect on the amastigote stage of $L$. donovani $[19,21,22]$. Moreover, compounds 3, 5 and $\mathbf{9}$ were active against a chloroquine-resistant strain (Indochina W2) of P. falciparum. These compounds had previously shown activity against $P$. falciparum chloroquine-sensitive 3D7 (3, 5 and 


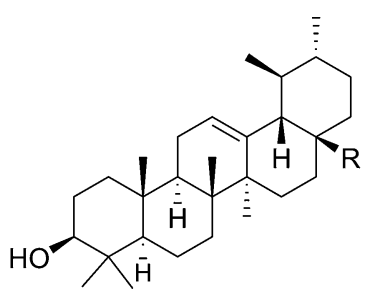

$1 \mathrm{R}=\mathrm{CH}_{3}$

$3 \mathrm{R}=\mathrm{COOH}$<smiles>OC1CS[S](O)C1</smiles>

6

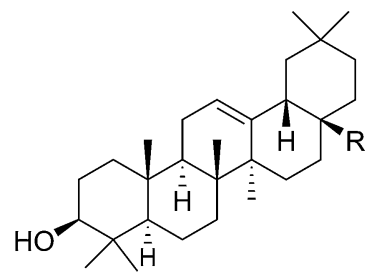

$2 \mathrm{R}=\mathrm{CH}_{3}$

$4 \mathrm{R}=\mathrm{COOH}$<smiles>OC1C[SH](O)CS1</smiles>

7

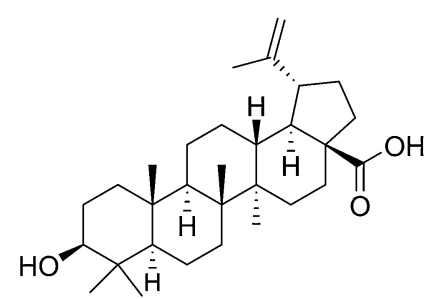

5<smiles>[R]C1=C(c2ccc(O)c([R])c2)Cc2cc(O)cc(O)c2C1=O</smiles>

$8 \mathrm{R} 1=\mathrm{OH} \quad \mathrm{R} 2=\mathrm{OH}$

$9 \quad \mathrm{R} 1=\mathrm{H} \quad \mathrm{R} 2=\mathrm{OH}$

$10 \mathrm{R} 1=\mathrm{OH}$ R2= ORham

Fig. 1 Structures of compounds produced by Pelliciera rhizophorae

Table 1 Antiparasitic activity $\left(\mathrm{IC}_{50}, \mu \mathrm{M}\right)$ of the isolated compounds from Pelliciera rhizophorae

\begin{tabular}{|c|c|c|c|c|}
\hline Compounds & L. donovani & P. falciparum & T. cruzi & Vero cells \\
\hline 1 & I & I & $19.0 \pm 0.6$ & I \\
\hline 2 & I & I & 1 & I \\
\hline 3 & $2.4 \pm 0.1$ & $21.9 \pm 0.6$ & । & $64.8 \pm 0.3$ \\
\hline 4 & $5.3 \pm 0.2$ & I & I & $140.8 \pm 0.5$ \\
\hline 5 & I & $18.0 \pm 0.4$ & । & $131.1 \pm 0.3$ \\
\hline 6 & 1 & I & I & I \\
\hline 7 & I & I & I & 1 \\
\hline 8 & $22.9 \pm 0.2$ & I & 1 & $154.9 \pm 0.6$ \\
\hline 9 & $12.6 \pm 0.2$ & $9.7 \pm 0.3$ & $13.0 \pm 0.4$ & I \\
\hline 10 & $3.4 \pm 0.1$ & 1 & I & I \\
\hline Anfotericine B & $1.0 \pm 0.12$ & ND & ND & ND \\
\hline Chloroquine & ND & $0.09 \pm 0.01$ & ND & ND \\
\hline Nifurtimox & ND & ND & $1.6 \pm 0.11$ & ND \\
\hline
\end{tabular}

I inactive at $10 \mu \mathrm{g} / \mathrm{mL}, N D$ not determined

9) and chloroquine-resistant K1 (9) [19, 23]. Finally, compounds $\mathbf{1}$ and $\mathbf{9}$ also showed bioactivity against T. cruzi, strain Tulahuen, clone C4 (Table 1). These compounds had previously exhibited activity against trypomastigotes of $T$. brucei rhodesiense which causes African trypanosomiasis $[24,25]$.

Although the antiparasitic activity of the isolated compounds is not comparable to that of controls, it is important to emphasize two important aspects, first the isolated compounds were evaluated against three different parasites of human importance so it is possible to describe some selectivity in the activity of P. rhizophorae components, and second these compounds showed low levels of cytotoxicity. According to this, compounds $1,4,5,8$ and 10 have selective activity against one parasite while compound $\mathbf{9}$ possess broad activity inhibiting the three evaluated parasites. Nevertheless, the main trouble with these compounds will be their low polarity, which gives them aqueous solubility problems, and therefore low absorption and limited bioavailability. Developing analogues with higher polarity and better biological activity would be a viable option to overcome this obstacle.

Infectious diseases, including causative agents of trypanosomiasis, leishmaniasis and malaria, are responsible for a high rate of mortality and morbidity each year in the countries with high levels of poverty. Due to the lack of treatment options, there is an urgent need to discover novel therapeutics options against these neglected tropical diseases. Thus, the discovery of new sources of antiparasitic agents is of great significance, because natural sources are one of the most affordable, especially for people in poor countries.

\section{$\alpha$-Glucosidase inhibition evaluation and kinetic studies}

Triterpenes 1-5 inhibited $\alpha$-glucosidase enzyme in a concentration-dependent manner with $\mathrm{IC}_{50}$ values of 1.45 , $0.02,1.08,0.98$ and $2.37 \mu \mathrm{M}$, respectively. All triterpenes were more potent against $\alpha$-glucosidase than acarbose (positive control, $\mathrm{IC}_{50} 217.7 \mu \mathrm{M}$ ). Given the structural 
similarities and biological activity among compounds 1-5, the minor substitutions of the central core (pentacyclic triterpene) does not appear to produce a significant difference in the $\alpha$-glucosidase inhibition. However, if we compare compound $\mathbf{2}$ with the other compounds, it can be inferred that presence of a gem dimethyl at position 20 and a methyl in position 28 , it confer a potent inhibitory activity to the pentacyclic core.

In order to obtain further evidence of the nature of the interaction of compounds $\mathbf{1 - 5}$ with $\alpha$-glucosidase kinetic analyses were carried out. Lineweaver-Burk plots [26] were constructed using different concentrations of substrate and triterpenes $\mathbf{1 - 5}$. The results in Fig. 2 indicated that 1-5 showed typical reversible competitive plots, with series of lines having the same y-intercept as the enzyme without inhibitors. These results suggested that compounds 1-5 bind to $\alpha$-glucosidase or to the substrate-enzyme complex. Acarbose also behaved as competitive inhibitor [27]. These results show that pentacyclic triterpene core is a potent competitive inhibitor of the $\alpha$-glucosidase enzyme.

With respect to the modulations of $\alpha$-glucosidase function by compounds $\mathbf{6}-\mathbf{1 0}$, metabolites $8(262.2 \mu \mathrm{M})$ and $9(29.8 \mu \mathrm{M})$ showed moderate inhibition while 6, 7 and 10 were inactive, so it can be hypothesized the main $\alpha$-glucosidase inhibitors produced by $P$. rhizophorae belongs to pentacyclic triterpenoid family.

\section{Docking study}

Taking into account the preliminary in vitro $\alpha$-glucosidase inhibition evaluations, the most active compounds (pentacyclic triterpenes) were selected to explain the experimental activities. Based on this, molecular docking study was conducted to evaluate the putative binding mode of compounds 1-5 into the human intestinal $\alpha$-glucosidase (PDB: 3TOP). Results indicate that all analyzed triterpenoid compounds bind mainly through hydrophobic interactions. Figure 3 shows the superposition of docking poses of compounds 1-5 and acarbose in the binding site. It is interesting to note that despite analyzed triterpenoids are mainly hydrophobic, they bind into the same site of acarbose that is a more polar compound. As expected, acarbose interacts with the binding site through many hydrogen bonds (Fig. 4a) and compounds 1-5 interact via hydrophobic interactions (Fig. 4b). However, all triterpenoids interact with Lys 1460 through formation of hydrogen bonds with $3 \beta-\mathrm{OH}$ group or via ionic interaction between the carboxylate group in the triterpenoid and the amine group of Lys 1460 (Fig. 5a, b). This interaction has some significance for enzyme inhibition since docking poses where the $3 \beta-\mathrm{OH}-\mathrm{Lys}$ hydrogen bond interaction was present had lower scores than docking poses with the carboxylate-Lys ionic interaction (see Table 2). In fact, docking poses with lower scores for compound $\mathbf{5}$ always displayed an ionic interaction with Lys 1460. Poses of compound 5 have fewer hydrophobic interactions than poses of compounds 1-4, and this could be a plausible explanation for its lower enzyme inhibition in comparison with the other compounds analyzed. Therefore, taking compound $\mathbf{5}$ as an outlier, there is a slight correlation between docking score and experimental $\mathrm{IC}_{50}$.

\section{Conclusions}

In summary, ten compounds were isolated from the endemic mangrove $P$. rhizophorae (five triterpenes, three flavonols and two dithiolanes). Dithiolane is the only core of the three evaluated lacking antiparasitic activity. Even though all compounds reported in this work have been reported from other sources, this is the first report of secondary metabolites produced by $P$. rhizophorae. There have been few new options for the treatment of neglected tropical diseases in half a century, therefore it is important to search for new sources of antiparasitic compounds to help global programs aimed at combating neglected diseases. P. rhizophorae represents a new natural source against parasitic protozoans which produces several compounds with selective activity (compounds $\mathbf{1}$, 4, 5, 8 and 10) and low levels of cytotoxicity. In addition, five pentacyclic triterpenes with potent $\alpha$-glucosidase inhibitory activity were isolated. These compounds exhibited a competitive type of inhibition against $S$. cerevisiae $\alpha$-glucosidase. All triterpenes showed higher inhibitory activity than acarbose. Definitely, in vitro inhibitory properties against $\alpha$-glucosidase enzyme are far superior to the antiparasitic properties of this plant. Therefore this plant might also be an interesting alternative for reducing levels of blood sugar of people affected by DM.

\section{Methods}

\section{General experimental procedures}

Melting point measurements were carried out on an Electrothermal apparatus and are uncorrected. NMR spectra were acquired on Jeol Eclipse $400 \mathrm{MHz}$. APCIHR-MS were acquired on a JEOL LC-mate mass spectrometer. The purification of the compounds was carried out on Agilent 1100 HPLC system equipped with a quaternary pump, a diode array detector and a reverse phase silica gel column (Phenomenex Synergy Hydro-RP, $250 \mathrm{~mm} \times 100 \mathrm{~mm}, 4 \mu \mathrm{m}$ ) or normal phase silica gel column (Sphereclone silica $250 \times 10 \mathrm{~mm}$ column) at a flow rate of $1.0 \mathrm{~mL} / \mathrm{min}$. TLC was performed on precoated silica gel 60 F254 plates (Merck). All solvents were HPLC grade and used without further purification [3, 28]. 


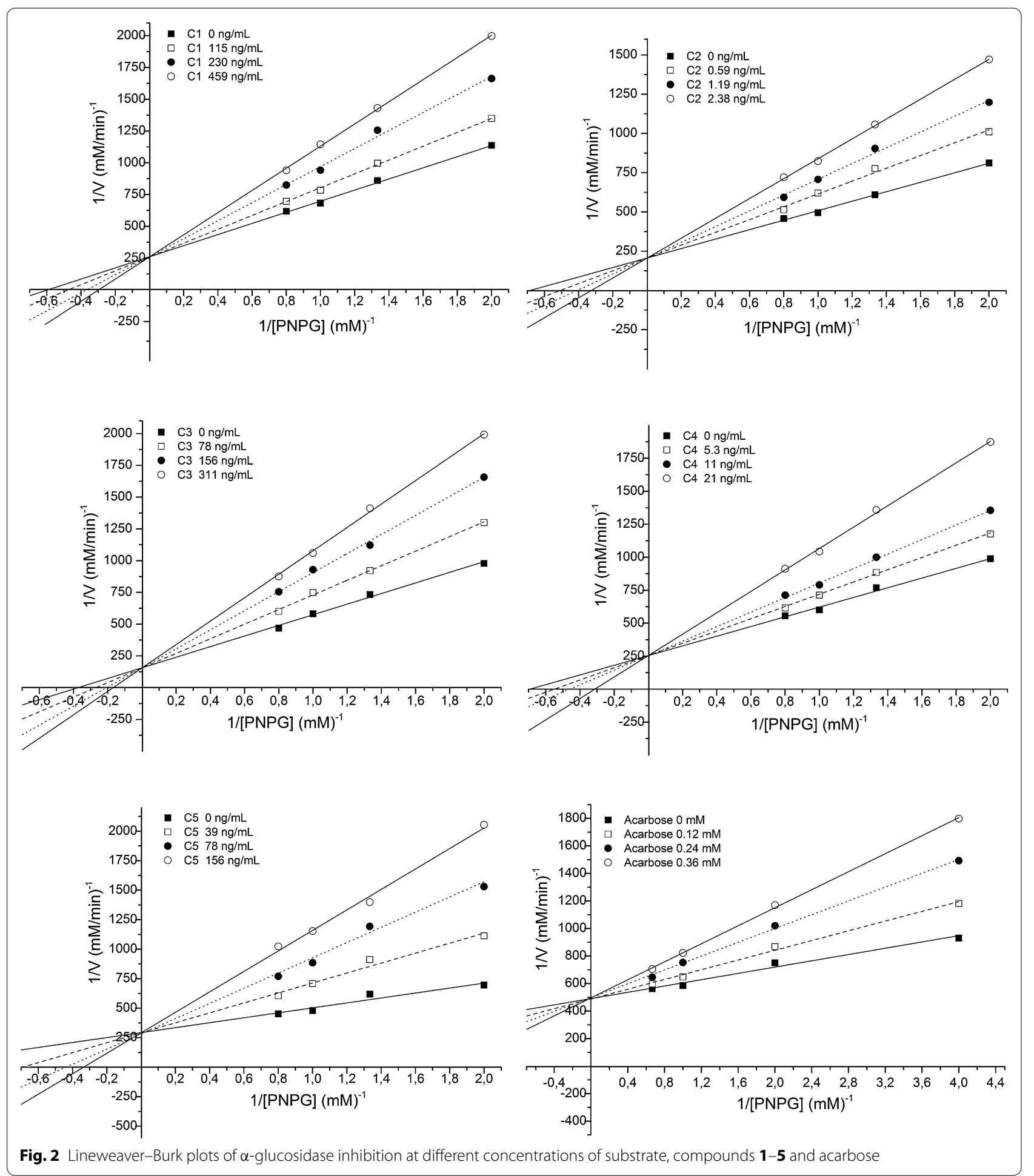

\section{Plant material and extract preparation}

P. rhizophorae (Pellicieraceae) leaves were collected at Punta Chame, Panama, in May 2012. This plant was identified by Alejandro De Sedas. A voucher specimen
(105833) has been deposited at the University of Panama Herbarium. After drying the fresh leaves and crushing in a standard blender to obtain $108 \mathrm{~g}$ of coarse powder, the extract was prepared by maceration with a mixture of 


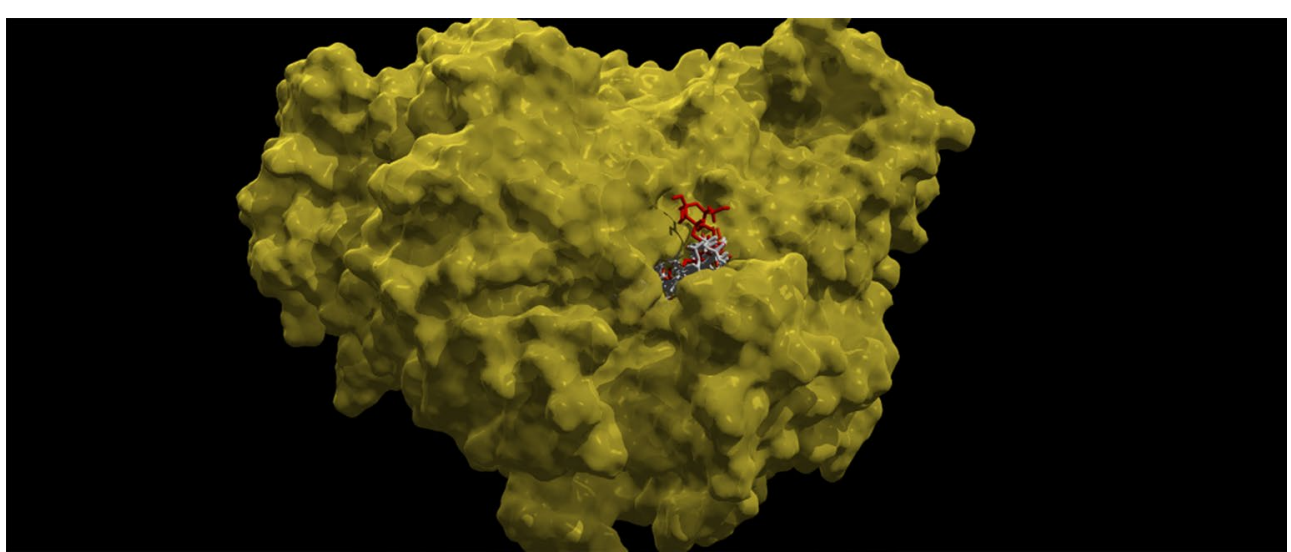

Fig. 3 Superposition of docking poses of compounds 1-5 (in white) and acarbose (in red)
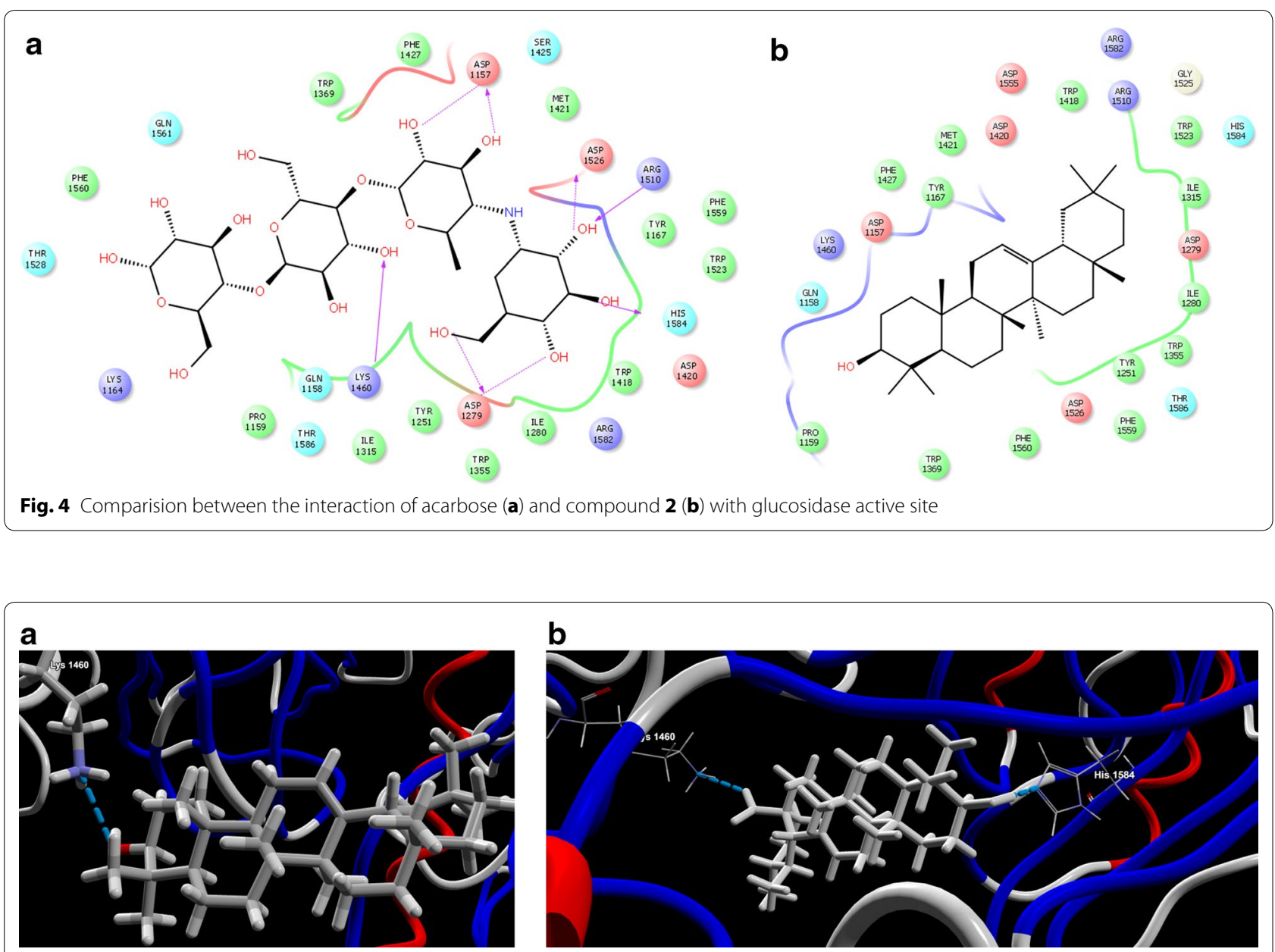

Fig. 5 Docking poses of compound $\mathbf{2}$ (a) and compound $\mathbf{3}(\mathbf{b})$. Interaction with Lys 1460 is highlighted

$\mathrm{MeOH}: \mathrm{CHCl}_{3}$ (1:1). Extract was concentrated to a semisolid paste using a Buchi Rotary Evaporator (R-215) to obtain $31 \mathrm{~g}$ of crude extract.

\section{Isolation of compounds}

The organic extract was fractionated by column chromatography on silica gel (100 g). The column was eluted 
Table 2 Rerank scores obtained during docking studies

\begin{tabular}{llcl}
\hline Compound & $\mathbf{I C}_{\mathbf{5 0}}$ (mM) & Rerank score & $\begin{array}{l}\text { Interaction } \\
\text { with Lys } \mathbf{1 4 2 0}\end{array}$ \\
\hline $\mathbf{1}$ & 1.45 & 33.4917 & Hydrogen bond \\
$\mathbf{2}$ & 0.02 & -55.6135 & Hydrogen bond \\
$\mathbf{3}$ & 1.08 & -6.54481 & lonic \\
$\mathbf{4}$ & 0.98 & -24.732 & Hydrogen bond \\
$\mathbf{5}$ & 2.37 & -14.5051 & lonic \\
& $\mathrm{r}^{2}$ & 0.3195 & \\
& $\mathrm{r}^{2}$ (5 as outlier) & 0.8642 & \\
\hline
\end{tabular}

with hexane, followed by a gradient of hexane:EtOAc $(1: 0 \rightarrow 0: 1)$ and finally with a gradient of EtOAc:MeOH $(1: 0 \rightarrow 1: 1)$. Altogether, 325 fractions $(100 \mathrm{ml}$ each) were collected and combined according to their TLC profiles to yield 37 primary fractions (FI to FXXXVII). Fraction FIX (5.77 g) was further subjected to silica gel column chromatography and eluted with a gradient of hexane:EtOAc $(1: 0 \rightarrow 0: 1)$. This process led to 17 secondary fractions (FIX-A to FIX-Q). Fraction FIX-D (407 mg) eluted with Hexane:EtOAc (8:2), was purified by normal phase HPLC (Sphereclone silica $250 \times 10 \mathrm{~mm}$ column, isocratic elution of $90 \%$ hexanes:10 \% EtOAc, UV detector at $254 \mathrm{~nm}$, flow of $1 \mathrm{~mL} / \mathrm{min}$ ) to afford $21 \mathrm{mg}$ of $\alpha$-amyrine (1) and $13 \mathrm{mg}$ of $\beta$-amyrine (2). Fraction FXIII (773 mg) eluted with Hexane:EtOAc (1:1), purified by normal phase HPLC (Sphereclone silica $250 \times 10 \mathrm{~mm}$ column, isocratic elution of 85 \% hexanes: 15 \% EtOAc, UV detector at $254 \mathrm{~nm}$, flow of $1 \mathrm{~mL} / \mathrm{min}$ ) yielded $37 \mathrm{mg}$ of ursolic acid (3), $27 \mathrm{mg}$ of oleanolic acid (4) and $7 \mathrm{mg}$ of betulinic acid (5). Fraction FXXVIII (1.78 g) was further subjected to silica gel column chromatography and eluted with a gradient of hexane:EtOAc $(1: 1 \rightarrow 0: 1)$ and EtOAc:MeOH (1:0 $\rightarrow$ 1:1). This process led to six secondary fractions (FXXVIII-A to FXXVIII-F). Fraction FXXVIII-A (98 mg) eluted with hexane:EtOAc (1:1) was purified by normal phase HPLC (Sphereclone silica $250 \times 10 \mathrm{~mm}$ column, isocratic elution of $25 \%$ hexanes:75 \% EtOAc, UV detector at $254 \mathrm{~nm}$, flow of $1 \mathrm{~mL} /$ $\mathrm{min}$ ) resulted in $2 \mathrm{mg}$ of brugierol (6) and $1.3 \mathrm{mg}$ of isobrugierol (7). Fraction FXXVIII-C (165 mg) eluted with $100 \%$ EtOAc, was purified by reverse phase HPLC (Synergi Hydro-RP $250 \times 10 \mathrm{~mm}$ column, isocratic elution of $40 \% \mathrm{MeOH}: 60 \% \mathrm{H}_{2} \mathrm{O}$, UV detector at $254 \mathrm{~nm}$, flow of $1.0 \mathrm{~mL} / \mathrm{min}$ ) to afford $3.4 \mathrm{mg}$ of Kaempferol (8) and $5.0 \mathrm{mg}$ of quercetin (9). Finally, fraction FXXXIII (95 mg), eluted with EtOAc:MeOH (1:1), was purified by reverse phase HPLC (Synergi Hydro-RP $250 \times 10 \mathrm{~mm}$ column, isocratic elution of $65 \% \mathrm{MeOH}: 35 \% \mathrm{H}_{2} \mathrm{O}$, UV detector at $254 \mathrm{~nm}$, flow of $1.0 \mathrm{~mL} / \mathrm{min}$ ) yielded $8 \mathrm{mg}$ of quercetrin (10).

\section{Spectral compounds data}

$\alpha$-amyrin (1) Colorless solid. m.p. $185-187{ }^{\circ} \mathrm{C}$. ${ }^{1} \mathrm{H}$-NMR $\left(\mathrm{CDCl}_{3}, 400 \mathrm{MHz}\right): \delta_{\mathrm{H}} 5.16(\mathrm{t}, J=3.6 \mathrm{~Hz}), 3.23(\mathrm{dd}$, $J=4.4,3.9 \mathrm{~Hz}), 1.96(\mathrm{td}, J=4.4,13.6 \mathrm{~Hz}), 1.85(\mathrm{~m}), 1.78$ $(\mathrm{td}, J=4.9,13.6 \mathrm{~Hz}), 1.00(\mathrm{~s}), 0.97(\mathrm{~s}), 0.94(\mathrm{~s}), 0.87(\mathrm{~s})$, $0.83(\mathrm{~d}, J=6.0 \mathrm{~Hz}), 0.79(\mathrm{sb}) 0.74(\mathrm{~d}, J=11.0 \mathrm{~Hz}) .{ }^{13} \mathrm{C}-$ NMR $\left(100 \mathrm{MHz}, \mathrm{CDCl}_{3}\right): \delta_{\mathrm{C}} 38.8(\mathrm{C}-1), 28.6(\mathrm{C}-2), 79.3$ (C-3), 38.8 (C-4), 55.2 (C-5), 18.3 (C-6), 32.4 (C-7), 40.6 (C-8), 47.7 (C-9), 36.9 (C-10), 23.3 (C-11), 124.4 (C-12), 139.6 (C-13), 42.1 (C-14), 27.3 (C-15), 26.6 (C-16), 33.7 (C-17), 59.1 (C-18), 39.6 (C-19), 39.7 (C-20), 31.2 (C-21), 41.5 (C-22), 28.1 (C-23), 15.7 (C-24), 15.6 (C-25), 16.8 (C-26), 23.3 (C-27), 28.1 (C-28), 17.5 (C-29), 21.4 (C-30). APCI-HR-MS $m / z 427.3893[\mathrm{M}+\mathrm{H}]^{+}$(calcd for $\left.\mathrm{C}_{30} \mathrm{H}_{51} \mathrm{O}, 427.3895\right)$.

$\beta$-amyrin (2) Colorless solid. m.p. 196-197 ${ }^{\circ} \mathrm{C} .{ }^{1} \mathrm{H}$ NMR $\left(\mathrm{CDCl}_{3}, 400 \mathrm{MHz}\right): \delta_{\mathrm{H}} 5.18(\mathrm{t}, J=3.5 \mathrm{~Hz}), 3.20(\mathrm{dd}$, $J=4.4,10.8 \mathrm{~Hz}), 1.90(\mathrm{td}, J=4.0,13.6 \mathrm{~Hz}), 1.81(\mathrm{~m}), 1.73$ $(\mathrm{td}, J=4.2,13.6 \mathrm{~Hz}), 1.19(\mathrm{~s}), 1.09(\mathrm{~s}), 0.96(\mathrm{~s}), 0.93(\mathrm{~s})$, $0.92(\mathrm{~d}, J=6.4 \mathrm{~Hz}), 0.84(\mathrm{~s}), 0.80(\mathrm{~s}), 0.72(\mathrm{~d}, J=10.8 \mathrm{~Hz})$. ${ }^{13} \mathrm{C}-\mathrm{NMR}\left(100 \mathrm{MHz}, \mathrm{CDCl}_{3}\right): \delta_{\mathrm{C}} 38.6(\mathrm{C}-1), 27.2(\mathrm{C}-2)$, 79.0 (C-3), 38.8 (C-4), 54.9 (C-5), 18.4 (C-6), 32.6 (C-7), 39.8 (C-8), 47.7 (C-9), 36.8 (C-10), 23.5 (C-11), 121.7 (C-12), 145.2 (C-13), 41.7 (C-14), 26.1 (C-15), 27.2 (C-16), 32.5 (C-17), 47.3 (C-18), 46.8 (C-19), 31.2 (C-20), 34.7 (C-21), 37.1 (C-22), 28.1 (C-23), 15.6 (C-24), 15.7 (C-25), 16.9 (C-26), 25.8 (C-27), 28.4 (C-28), 33.7 (C-29), 23.7 (C-30). APCI-HR-MS $m / z 427.3896[\mathrm{M}+\mathrm{H}]^{+}$(calcd for $\mathrm{C}_{30} \mathrm{H}_{51} \mathrm{O}$, 427.3895).

Ursolic acid (3). Colorless solid. m.p. $291-292{ }^{\circ} \mathrm{C} .{ }^{1} \mathrm{H}$ $\operatorname{NMR}\left(\mathrm{CDCl}_{3}, 400 \mathrm{MHz}\right): \delta_{\mathrm{H}} 5.28(\mathrm{t}, J=3.6 \mathrm{~Hz}), 3.21(\mathrm{dd}$, $J=10.2,4.4 \mathrm{~Hz}), 2.18(\mathrm{~d}, J=11.7 \mathrm{~Hz}), 1.19(\mathrm{~m}), 2.00(\mathrm{dd}$, $J=13.0,4.0 \mathrm{~Hz}), 1.25(\mathrm{~s}), 0.98(\mathrm{~s}), 0.77(\mathrm{~s}), 1.08(\mathrm{~s}), 1.14$ $(\mathrm{s}), 0.93(\mathrm{~d}, J=6.5 \mathrm{~Hz}), 0.91(\mathrm{~d}, J=5.9 \mathrm{~Hz}) .{ }^{13} \mathrm{C}$ NMR $\left(\mathrm{CDCl}_{3}, 100 \mathrm{MHz}\right): \delta_{\mathrm{C}} 39.2(\mathrm{C}-1), 27.5(\mathrm{C}-2), 78.5(\mathrm{C}-3)$, 38.7 (C-4), 55.5 (C-5), 18.3 (C-6), 33.1 (C-7), 39.6 (C-8), 47.8 (C-9), 36.9 (C-10), 16.6 (C-11), 125.7 (C-12), 138.4 (C-13), 41.7 (C-14), 29.5 (C-15), 24.1 (C-16), 47.7 (C-17), 53.1 (C-18), 39.2 (C-19), 39.2 (C-20), 30.5 (C-21), 36.9 (C-22), 28.0 (C-23), 15.2 (C-24), 14.8 (C-25), 16.4 (C-26), 23.1 (C-27), 180.4 (C-28), 22.9 (C-29), 22.8 (C-30). APCIHR-MS $m / z 457.3635[\mathrm{M}+\mathrm{H}]^{+}$(calcd for $\mathrm{C}_{30} \mathrm{H}_{49} \mathrm{O}_{3}$, 457.3637).

Oleanolic acid (4) Colorless solid. UV (MeOH) m.p. 299-301 ${ }^{\circ} \mathrm{C}$.; ${ }^{1} \mathrm{H}$ NMR $\left(\mathrm{CDCl}_{3}, 400 \mathrm{MHz}\right): \delta_{\mathrm{H}} 5.24(\mathrm{t}$, $J=3.6 \mathrm{~Hz}), 3.21(\mathrm{dd}, J=10.2,4.4 \mathrm{~Hz}), 2.82(\mathrm{dd}, J=12.7$, $4.3 \mathrm{~Hz}), 0.96(\mathrm{~s}), 0.78(\mathrm{~s}), 0.84(\mathrm{~s}), 0.76(\mathrm{~s}), 1.25(\mathrm{~s}), 0.87$ (s), 0.93 (s). ${ }^{13} \mathrm{C}$ NMR $\left(\mathrm{CDCl}_{3}, 100 \mathrm{MHz}\right): \delta_{\mathrm{C}} 38.6(\mathrm{C}-1)$, 26.7 (C-2), 78.5 (C-3), 39.2 (C-4), 55.5 (C-5), 18.3 (C-6), 32.6 (C-7), 39.6 (C-8), 48.1 (C-9), 37.0 (C-10), 22.7 (C-11), 122.4 (C-12), 144.1 (C-13), 42.0 (C-14), 27.7 (C-15), 22.8 (C-16), 46.7 (C-17), 41.5 (C-18), 46.1 (C-19), 30.4 (C-20), 33.7 (C-21), 32.3 (C-22), 28.8 (C-23), 14.7 (C-24), 15.1 
(C-25), 16.5 (C-26), 25.2 (C-27),180.4 (C-28), 32.8 (C-29), $23.3(\mathrm{C}-30)$. APCI-HR-MS $m / z 457.3639[\mathrm{M}+\mathrm{H}]^{+}$(calcd for $\left.\mathrm{C}_{30} \mathrm{H}_{49} \mathrm{O}_{3}, 457.3637\right)$.

Betulinic acid (5) Colorless solid. m.p. $317-319{ }^{\circ} \mathrm{C} .{ }^{1} \mathrm{H}$ NMR $\left(\mathrm{CDCl}_{3}, 400 \mathrm{MHz}\right): \delta_{\mathrm{H}} 4.66(\mathrm{~s}), 3.79$ (dd, $J=10.0$, $5.5 \mathrm{~Hz}), 2.39(\mathrm{~m}), 2.10-2.20(\mathrm{~m}) 1.66(\mathrm{~s}), 1.00(\mathrm{~s}), 0.96(\mathrm{~s})$, 0.94 (s), 0.80 (s), $0.74(\mathrm{~s}) .{ }^{13} \mathrm{C} \mathrm{NMR}\left(\mathrm{CDCl}_{3}, 100 \mathrm{MHz}\right): \delta_{\mathrm{C}}$ 38.9 (C-1), 27.8 (C-2), 79.0 (C-3), 38.7 (C-4), 55.5 (C-5), 18.3 (C-6), 34.0 (C-7), 40.9 (C-8), 50.4 (C-9), 37.3 (C-10), 20.7 (C-11), 25.2 (C-12), 37.3 (C-13), 42.7 (C-14), 30.1 (C-15), 29.3 (C-16), 56.5 (C-17), 46.4 (C-18), 49.1 (C-19), 150.4 (C-20), 29.8 (C-21), 34.1 (C-22), 28.0 (C-23), 15.4 (C-24), 16.0 (C-25), 16.1 (C-26), 14.8 (C-27), 180.0 (C-28), 109.6 (C-29), 19.1 (C-30). APCI-HR-MS m/z 457.3636 $[\mathrm{M}+\mathrm{H}]^{+}$(calcd for $\left.\mathrm{C}_{30} \mathrm{H}_{49} \mathrm{O}_{3}, 457.3637\right)$.

Quercetin (6) Yellow powder, m.p. 313-315. ${ }^{1} \mathrm{H}$ NMR (DMSO-D, $400 \mathrm{MHz}) \delta_{\mathrm{H}} 6.19(\mathrm{~d}, J=2.0, \mathrm{H}-6), 6.41(\mathrm{~d}$, $J=2.0, \mathrm{H}-8), 7.69\left(\mathrm{~d}, J=2.2, \mathrm{H}-2^{\prime}\right), 6.89\left(\mathrm{~d}, J=8.5, \mathrm{H}-5^{\prime}\right)$, $7.55\left(\mathrm{~d}, J=8.5,2.2, \mathrm{H}-6^{\prime}\right), 12.98(1 \mathrm{H}, \mathrm{s}, 5-\mathrm{OH}) .{ }^{13} \mathrm{C} \mathrm{NMR}$ (DMSO-D $6,100 \mathrm{MHz}) \delta_{\mathrm{C}} 145.1$ (C-2), 135.8 (C3), 175.9 (C-4), 103.1 (C-4a), 160.8 (C-5), 98.3 (C-6), 164.0 (C-7), 93.41 (C-8), 156.2 (C-9), $122.0\left(\mathrm{C}-1^{\prime}\right), 115.10\left(\mathrm{C}-2^{\prime}\right), 146.9$ $\left(\mathrm{C}-3^{\prime}\right), 147.8\left(\mathrm{C}-4^{\prime}\right), 115.7\left(\mathrm{C}-5^{\prime}\right), 120.1$ (C-6'). APCIHR-MS $m / z 303.0569[\mathrm{M}+\mathrm{H}]^{+}$(calcd for $\mathrm{C}_{15} \mathrm{H}_{10} \mathrm{O}_{7}$, 303.0505).

Kaempferol (7) Pale yellow needles, m.p. $276-278{ }^{\circ} \mathrm{C}$. ${ }^{1} \mathrm{H}$ NMR (DMSO-D, $\left.400 \mathrm{MHz}\right) \delta_{\mathrm{H}} 6.19(\mathrm{~d}, J=1.9$, H-6), 6.45 (d, $J=1.9, \mathrm{H}-8), 8.04$ (d, $\left.J=8.9, \mathrm{H}-2^{\prime}\right), 6.93$ $\left(\mathrm{d}, J=8.9, \mathrm{H}-3^{\prime}\right), 6.93\left(\mathrm{~d}, J=8.9, \mathrm{H}-5^{\prime}\right), 8.04(\mathrm{~d}, J=8.9$, H-6'), 9.35 (br s, 3-OH), 10.10 (br s, 4-OH), 12.48 (br s, $5 \mathrm{OH}), 10.85$ (s, 7-OH). ${ }^{13} \mathrm{C}$ NMR (DMSO-D, $\left.100 \mathrm{MHz}\right)$

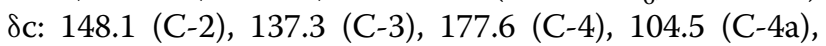
162.8 (C-5), 99.3 (C-6), 165.5 (C-7), 94.5 (C-8), 160.7 (C-8a), 123.9 (C-1), 130.9 (C-2), 116.5 (C-3), 158.3 (C-4), 116.4 (C-5), 130.9 (C-6) APCI-HR-MS $m / z 287.0606$ $[\mathrm{M}+\mathrm{H}]^{+}$(calcd for $\left.\mathrm{C}_{15} \mathrm{H}_{11} \mathrm{O}_{6}, 287.0556\right)$.

Quercetrin (8) Amorphous yellow powder, m.p. 181-182 ${ }^{\circ} \mathrm{C},{ }^{1} \mathrm{H}$ NMR (DMSO-D $\left.6,400 \mathrm{MHz}\right): \delta_{\mathrm{H}}$ $7.36(\mathrm{dd}, J=1.8,8.1 \mathrm{~Hz}), 7.30(\mathrm{~d}, J=1.8 \mathrm{~Hz}), 6.87(\mathrm{~d}$, $J=8.4 \mathrm{~Hz}), 6.40(\mathrm{~d}, J=1.8 \mathrm{~Hz}), 6.21(\mathrm{~d}, J=2.2 \mathrm{~Hz}), 5.25$ $(\mathrm{d}, J=1.5 \mathrm{~Hz}), 4.20(\mathrm{~m}), 3.73(\mathrm{dd}, J=3.4,9.2 \mathrm{~Hz}), 3.38$ (m), $3.31(\mathrm{~m}), 0.90(\mathrm{~d}, J=6.6 \mathrm{~Hz}) ;{ }^{13} \mathrm{C}$ NMR (DMSO-D 6 , $100 \mathrm{MHz}): \delta_{\mathrm{C}} 178.1(\mathrm{C}-4), 164.8$ (C-7), 161.9 (C-5), 157.5 (C-9), 157.0, (C-2) $149.0\left(\mathrm{C}-3^{\prime}\right), 145.8\left(\mathrm{C}-4^{\prime}\right), 134.8$ (C-3), $121.6\left(\mathrm{C}-1^{\prime}\right), 121.2\left(\mathrm{C}-6^{\prime}\right), 116.2\left(\mathrm{C}-2^{\prime}\right), 116.0\left(\mathrm{C}-5^{\prime}\right), 104.7$ (C-10), $102.4\left(\mathrm{C}-1^{\prime \prime}\right), 99.2(\mathrm{C}-6), 94.2(\mathrm{C}-8), 71.5\left(\mathrm{C}-5^{\prime \prime}\right)$, $71.2\left(\mathrm{C}-3^{\prime \prime}\right), 70.9\left(\mathrm{C}-2^{\prime \prime}\right), 70.6\left(\mathrm{C}-4^{\prime \prime}\right), 18.1\left(\mathrm{C}-6^{\prime \prime}\right)$; APCIHR-MS m/z 449.1079 $[\mathrm{M}+\mathrm{H}]^{+}, \mathrm{C}_{21} \mathrm{H}_{21} \mathrm{O}_{11}$ calcd for 449.1084).

Brugierol (9) Colorless solid, m.p. 88-89 ${ }^{\circ} \mathrm{C},{ }^{1} \mathrm{H}$ NMR $\left(\mathrm{CD}_{3} \mathrm{Cl}, 400 \mathrm{MHz}\right): \delta_{\mathrm{H}} 5.23$ (bs, H-4), 3.74 (dd, $J=11.0,6.0, \mathrm{H}-5 \mathrm{~b}), 3.53$ (dd, $J=12.0,6.0, \mathrm{H}-3 \mathrm{a}), 3.41$ (dd, $J=12.0,2.1, \mathrm{H}-3 \mathrm{~b}), 3.34$ (dd, $J=11.0,6.0, \mathrm{H}-5 \mathrm{a})$.
${ }^{13} \mathrm{C}\left(\mathrm{CD}_{3} \mathrm{Cl}, 100 \mathrm{MHz}\right): \delta_{\mathrm{C}} 43.3(\mathrm{C}-3), 75.8$ (C-4), 70.0 (C-5). APCI-HR-MS $\mathrm{m} / z 139.9770[\mathrm{M}+\mathrm{H}]^{+}$(calcd for $\left.\mathrm{C}_{3} \mathrm{H}_{7} \mathrm{O}_{2} \mathrm{~S}_{2}, 139.9767\right)$.

Iso-brugierol (10) Colorless solid, m.p. $82-83{ }^{\circ} \mathrm{C},{ }^{1} \mathrm{H}$ NMR $\left(\mathrm{CD}_{3} \mathrm{Cl}, 400 \mathrm{MHz}\right): \delta_{\mathrm{H}} 4.71$ (bs, H-4), 4.10 (dd, $J=10.5,1.0, \mathrm{H}-5 \mathrm{~b}$ ), 4.08 (dd, $J=13.0,1.0, \mathrm{H}-3 \mathrm{~b}), 3.63$ (dd, $J=10.5,3.8, \mathrm{H}-5 \mathrm{a}), 3.02$ (dd, $J=13.0,3.8, \mathrm{H}-5 \mathrm{~b}$ ). ${ }^{13} \mathrm{C}\left(\mathrm{CD}_{3} \mathrm{Cl}, 100 \mathrm{MHz}\right): \delta_{\mathrm{C}} 48.1$ (C-3), 80.2 (C-4), 67.8 (C-5). APCI-HR-MS $m / z$ 139.9764 $[\mathrm{M}+\mathrm{H}]^{+}$(calcd for $\left.\mathrm{C}_{3} \mathrm{H}_{7} \mathrm{O}_{2} \mathrm{~S}_{2}, 139.9767\right)$.

\section{Culture procedure}

Promastigotes cultures of $L$. donovani are maintained in continuous log phase growth in Liver Infusion Tryptose (LIT) Medium, pH 7.2, supplemented with $10 \%$ Fetal Bovine Serum (FBS) at $28{ }^{\circ} \mathrm{C}$. For promastigote transformation into amastigote forms, $1 \mathrm{~mL}$ of promastigotes $\log$ phase culture is transferred into $5 \mathrm{~mL}$ of Medium 199 Modified (SIGMA-Cat M3769) pH 5.5, supplemented with $0.1 \mathrm{~g} / \mathrm{L}$ L-glutamine, $2.2 \mathrm{~g} / \mathrm{L}$ sodium bicarbonate, $2 \mathrm{~g}$ Glucose, $5 \mathrm{~mL}$ penicillin-streptomycin and $20 \% \mathrm{FBS}$ and maintained at $35^{\circ} \mathrm{C}$ until its use for bioassays.

Antiplasmodial activity is evaluated using a chloroquine-resistant strain (Indochina W2) of P. falciparum. The cultures are kept in synchrony by thermal cycling incubation [29] and are maintained in continuous log phase growth in RPM-I1640 medium (SIGMA) supplemented with $2 \%$ washed human $\mathrm{O} R$ positive (+) erythrocytes, $25 \mathrm{mM}$ HEPES, $32 \mathrm{nM} \mathrm{NaHCO}$, and $10 \%$ Human Serum from an $\mathrm{O} \mathrm{Rh}+$ donor. All cultures and assays are conducted at $37{ }^{\circ} \mathrm{C}$ under an atmosphere of $5 \% \mathrm{CO}_{2}$ and $5 \% \mathrm{O}_{2}$, with a balance of $\mathrm{N}_{2}(90 \%)$.

T. cruzi (Tulahuen) C4 strain lactosidase (Lac Z) gene [30]. The strain is maintained on VERO Cells (African Green Monkey cell line obtained from ATCC on 2006), grown in monolayers in RPM-I1640 medium, supplemented with $10 \%$ heat inactivated FBS. All cultures and assays are conducted at $37{ }^{\circ} \mathrm{C}$ under an atmosphere of $5 \% \mathrm{CO}_{2} / 95 \%$ air mixture.

\section{In vitro antiparasitic assays}

Dry samples were diluted in 100 \% DMSO (dimethylsulfoxide) to obtain a concentration of $4 \mathrm{mg} / \mathrm{mL}$. Samples are used immediately in the bioassay and stored at $-20{ }^{\circ} \mathrm{C}$ in the dark until results are obtained. All assays are performed in sterile 96-well microtitre culture plates (Costar Cat 3595). In a primary screening samples are tested in duplicate wells at a final concentration of $10 \mu \mathrm{g} /$ $\mathrm{mL}$. If activity is found (growth Inhibition $>75 \%$ for $L$. donovani and P. falciparum and growth Inhibition $>50 \%$ for T. cruzi) then an assessment of the concentration that inhibits $50 \%$ of growth $\left(\mathrm{IC}_{50}\right)$ is carried out with four concentrations, by duplicates. The $\mathrm{IC}_{50}$ is analyzed with 
the Excel Add-On software LSW Data Analysis Tool. The concentration that inhibited the growth of the parasites to $50 \%\left(\mathrm{IC}_{50}\right)$ was calculated through the inhibition curve of the obtained optical density values, and compared to the untreated controls.

L. donovani and P. falciparum A DNA cross linking agent is used to determine the amount of parasites in culture. After 48 and $72 \mathrm{~h}$ incubation, respectively, $1 \%$ PicoGreen ${ }^{\circledR}$ solution is added to all wells in the dark. After shaking, the plate is taken into a microplate reader employing 485/20 nm excitation and 528/20 nm emission filter sets. Amphotericin B was used as a positive control for Leishmania; the typical $\mathrm{IC}_{50}$ response of $L$. donovani to this drug is $70-120 \mathrm{ng} / \mu \mathrm{l}$. Chloroquine served as a positive control for $P$. falciparum $\left(\mathrm{IC}_{50}=80-100 \mathrm{nM}\right)$ [3].

T. cruzi In this assay, a colorimetric method is used to determine the inhibition of parasite growth as detected by reduction of $\beta$-galactosidase $(\beta-\mathrm{Gal})$ as a reporter gene, expressed by the Tulahuen clone C4 of T. cruzi [22]. Assays are performed on trypomastigotes, the intracellular form of the parasite infecting African green monkey kidney (VERO) cells, exposed during $120 \mathrm{~h}$ to different concentrations $(50,10$ and $2 \mu \mathrm{g} / \mathrm{mL}$ ) of the test substance. The resulting colour from the cleavage of chlorophenol red- $\beta$-D-galactoside (CPRG) by $\beta$-Gal expressed by the parasite, was measured using a Benchmark BioRad microplate reader at $570 \mathrm{~nm}$. Nifurtimox was used as a positive control $\left(\mathrm{IC}_{50} 0.15-13.4 \mu \mathrm{M}\right)[3,31]$.

\section{Cytotoxicity bioassay}

Vero cells were seeded in 96-well plates in RPM-I1640 medium supplemented with $10 \%$ FBS and $1 \%$ penicillin/streptomycin. The cells were allowed to grow for $24 \mathrm{~h}$ before adding the test compounds, dissolved in DMSO, to final concentrations of $10,4,0.2$ and $0.08 \mu \mathrm{g} / \mathrm{mL}$. A sample with only a volume of DMSO similar to the added volume in the compounds samples was placed as a negative control in all plates. All samples were incubated for five days before staining and examining for reduction of 3-(4,5-dimethylthiazol-2-yl)-2,5-diphenyltetrazolium bromide (MTT) and analyzed $4 \mathrm{~h}$ later in a color plate reader at $570 \mathrm{~nm}$.

\section{$\alpha$-Glucosidase inhibitory assay}

The $\alpha$-glucosidase inhibitory assay was performed according to Chan and collaborators (2010) [32], with modifications. $\alpha$-glucosidase from baker's yeast purchased from Sigma Chemical Co. The inhibition was measured spectrophotometrically at $\mathrm{pH} 7.0$ and $37{ }^{\circ} \mathrm{C}$ employing $2 \mathrm{mM}$ p-nitrophenyl $\alpha$-D-glucopyranoside (PNP-G) as a substrate and $32 \mathrm{mU} / \mathrm{mL}$ of enzyme, in $100 \mathrm{mM}$ potassium phosphate buffer (enzyme stock).
Acarbose was dissolved in phosphate buffer, and serial dilutions (in order to obtain the $\mathrm{IC}_{50}$ ) were prepared and employed as positive control. The absorbance (A) of 4-nitrophenol released by the hydrolysis of PNP-G was measured at $400 \mathrm{~nm}$ by Synergy HT Bio Tek microplate spectrophotometer. A $20 \mu \mathrm{L}$ of acarbose or test compounds solution was incubated for 7 min with $150 \mu \mathrm{L}$ of enzyme stock at $37{ }^{\circ} \mathrm{C}$. After incubating, $150 \mu \mathrm{L}$ of substrate was added and further incubated for $20 \mathrm{~min}$ at $37{ }^{\circ} \mathrm{C}$. All assays are performed in 96-well microplates (Greiner bio-one 655101) in duplicate. The activity of samples was calculated as a percentage in comparison to a control (DMSO or MeOH instead of sample solution) according with the following equation:

$\%$ Inhibition $=\left(\left(\Delta A_{\text {control }}-\Delta A_{\text {sample }}\right) / \Delta A_{\text {control }}\right) \times 100 \%$

The concentration required to inhibit activity of the enzyme by $50 \%\left(\mathrm{IC}_{50}\right)$ was calculated by regression analysis [33].

\section{Docking study}

All ligands were constructed in Spartan'10 [34], and their geometry was optimized using MMFF force field. Protein-ligand docking studies were carried out based on the crystal structures for C-terminal domain of human intestinal $\alpha$-glucosidase (PDB: 3TOP) [35] which was retrieved from the Protein Data Bank [36]. Prior to docking, all of the solvent molecules and the co-crystallized ligand was removed. Molecular docking calculations were performed using Molegro Virtual Docker v. 6.0.1 [37]. A sphere of $15 \AA$ radius was centered in the binding site for searching. Experimental data indicates that these compounds are competitive inhibitors; thus the active site was chosen as the binding site. Protonation states and assignments of the charges on each protein were based on standard templates as part of the Molegro Virtual Docker program, and no other charges were necessary to set. Flexible ligand models were used in the docking and subsequent optimization scheme. Different orientations of the ligands were searched and ranked based on their energy scores. The RMSD threshold for multiple cluster poses was set to $<1.00 \AA$. The docking algorithm was set to 5000 maximum iterations with a simplex evolution population size of 100 and a minimum of 50 runs for each ligand. After docking, a number of further scores were calculated including the binding affinity (MolDock Score) and re-ranking score (Rerank Score). The re-ranking score utilizes a more advanced scoring scheme than that used during docking and is often more useful for accurate ranking of the poses. Poses with lower score were selected for further analysis 
To assess the efficacy of this procedure for finding low energy solutions, the co-crystallized ligand (acarbose) was also docked. The top ranking score was recorded, and the RMSD of that pose from the corresponding crystal coordinates calculated. RMSD was lower than $2 \AA$, indicating that the methodology used in the molecular docking simulation is appropriate.

\section{Authors' contributions}

Conceived and designed the experiments: SM-L. Performed the experiments: DL, LC, CS, ML-M, SM-L. Analyzed the data: SM-L, LC, ML-M. Wrote the paper: $M L-M, L C, D L, C S, S M-L$. All authors read and approved the final manuscript.

\section{Author details}

${ }^{1}$ Center for Drug Discovery and Biodiversity, Institute for Scientific Research and Technology Services (INDICASAT), Clayton, P.O. Box 0843-01103, Panama City, Republic of Panama. ${ }^{2}$ Department of Biotechnology, Acharya Nagarjuna University, Nagarjuna Nagar, Guntur 522510, India. ${ }^{3}$ Department of Organic Chemistry, Chemistry School, Faculty of Natural Sciences, Exact and Technology, University of Panama, P.O. Box 3366, Panama City, Republic of Panama. ${ }^{4}$ Center for Cellular and Molecular Biology of Diseases, Institute for Scientific Research and Technology Services (INDICASAT), Clayton, P.O. Box 0843-01103, Panama City, Republic of Panama. ${ }^{5}$ Facultad de Ciencias Químicas, Universidad La Salle, Benjamín Franklin 47, Cuauhtémoc, 06140 Mexico City, Mexico.

\section{Acknowledgements}

We would like to thank the government of Panama (ANAM) for granting permission to make the collections; to A. De Sedas for the taxonomic identification and Juan Fernandez for technical support. D.L. was supported by funds from the National Secretariat of Science, Technology and Innovation (SENACYT) doctoral grant 270-2011-154. L.C and S.M-L. were supported by funds from the National Research System (SNI, SENACYT) [L. C. (SNI-282014) and S.M-L. (SNI-32-2014)]. We thank M. Ng, A. Almanza and L. Herrera for performing Chagas', Leishmania and Malaria assays. Dr. Frederick Buckner (Department of Medicine, University of Washington, Seattle, USA), Max Grogl and Lucia Gerena of Division (Experimental Therapeutics, WRAIR, Silver Spring, M.D.) are acknowledged for kindly providing T. cruzi, L. donovani and P. falciparum respectively.

\section{Compliance with ethical guidelines}

\section{Competing interests}

The authors declare that they have no competing interests.

Received: 16 June 2015 Accepted: 11 September 2015

Published online: 28 September 2015

\section{References}

1. WHO. Neglected tropical diseases. http://www.who.int/neglected_diseases/diseases/en/. Accessed 1 Sept 2015

2. Ndjonka D, Rapado LN, Silber AM, Liebau E, Wrenger C (2013) Natural products as a source for treating neglected parasitic diseases. Int J Mol Sci 14:3395-3439

3. Martínez-Luis S, Cherigo L, Higginbotham S, Arnold E, Spadafora C, Ibañez A, Gerwick WH, Cubilla-Rios L (2011) Screening and evaluation of antiparasitic and in vitro anticancer activities of panamanian endophytic fungus. Int Microbiol 14:95-102

4. WHO. Diabetes. http://www.who.int/topics/diabetes_mellitus/en/. Accessed 1 Sept 2015

5. American Diabetes Association (2010) Diagnosis and classification of diabetes mellitus. Diabetes Care 33(suppl 1):S67-S74

6. Spalding M, Kainuma M, Collins L (2010) World atlas of mangroves. Earthscan Ltd, London

7. Bandaranayake WM (1998) Traditional and medicinal uses of mangroves. Mangroves and Salt Marshes 2:133-148
8. Bandaranayake WM (2002) Bioactivities, bioactive compounds and chemical constituents of mangrove plants. Wetlands Ecol Manage 10:421-452

9. Wu J, Xiao Q, Xu J, Li MY, Pan JY, Yang MH (2008) Natural products from true mangrove flora: source, chemistry and bioactivities. Nat Prod Rep 25:955-981

10. Wolbiś M, Olszewska M, Wesołowski WJ (2001) Triterpenes and sterols in the flowers and leaves of Prunus spinosa L. (Rosaceae). Acta Pol Pharm 58:459-462

11. Ragasa CY, Caro JL, Shen C-C (2011) Triterpenes and Sterol from Artocarpus ovatus. JAPS 4:07-11

12. Ogwuche CE, Amupitan JO, Ndukwe IG, Ayo RG (2014) Isolation and biological activity of the triterpene $\mathbf{B}$-amyrin from the aerial plant parts of Maesobotrya barteri (Baill). Med Chem 4:729-733

13. Uddin GHW, Siddiqui BSH, Alam M, Sadat A, Ahmad A, Uddin A (2011) Chemical constituents and phytotoxicity of solvent extracted fractions of stem bark of Grewia optiva Drummond ex burret, Middle-East. J Sci Res 8:85-91

14. Wan C, Yu Y, Zhou S, Tian S, Cao S (2011) Isolation and identification of phenolic compounds from Gynura divaricata leaves. Pharmacogn Mag 7:101-108

15. Fang XK, Gao J, Zhu DN (2008) Kaempferol and quercetin isolated from Euonymus alatus improve glucose uptake of 3T3-L1 cells without adipogenesis activity. Life Sci 82:615-622

16. Hanamura T, Hagiwara T, Kawagishi H (2005) Structural and functional characterization of polyphenols isolated from Acerola (Malpighia emarginata DC.) fruit. Biosci Biotechnol Biochem 69:280-286

17. Bao S, Deng Z, Fu H, Proksch P, Lin W (2005) Diterpenes and disulfides from the marine mangrove plant Bruguiera sexangula var. rhynchopetala. Helv Chim Acta 88:2757-2763

18. Homhual S, Zhang HJ, Bunyapraphatsara N, KondratyukTP, Santarsiero BD, Mesecar AD, Herunsalee A, Chaukul W, Pezzuto JM, Fong HH (2006) Bruguiesulfurol, a new sulfur compound from Bruguiera gymnorrhiza. Planta Med 72:255-260

19. Moulisha B, Kumar GA, Kanti HP (2010) Anti-leishmanial and Anti-cancer Activities of a Pentacyclic Triterpenoid Isolated from the Leaves of Terminalia arjuna Combretaceae. Trop J Pharm Res 9:135-140

20. Melo T, Bonardo V, Gattass C, Magri F, Fiorino P, Farah V, Fonteles M, Delorenzi J (2010) Leishmanicide activity of oleanolic acid against promastigotes of Leishmania braziliensis and Leishmania chagasi. Planta Med 76:441

21. da Silva ER, do Maquiaveli CC, Magalhães PP (2012) The leishmanicidal flavonols quercetin and quercitrin target Leishmania (Leishmania) amazonensis arginase. Exp Parasitol 130:183-188

22. Marín C, Boutaleb-Charki S, Díaz JG, Huertas O, Rosales MJ, Pérez-Cordon G, Guitierrez-Sánchez R, Sánchez-Moreno M (2009) Antileishmaniasis activity of flavonoids from Consolida oliveriana. J Nat Prod 72:1069-1074

23. Ganesh D, Fuehrer HP, Starzengrüber P, Swoboda P, Khan WA, Reismann JA, Mueller MS, Chiba P, Noedl H (2012) Antiplasmodial activity of flavonol quercetin and its analogues in Plasmodium falciparum: evidence from clinical isolates in Bangladesh and standardized parasite clones. Parasitol Res 110:2289-2295

24. Mwangi ESK, Keriko JM, Machocho AK, Wanyonyi AW, Malebo HM, Chhabra SC, Tarus PK (2010) Antiprotozoal activity and cytotoxicity of metabolites from leaves of Teclea trichocarpa. J Med Plants Res 4:726-731

25. Tasdemir D, Kaiser M, Brun R, Yardley V, Schmidt TJ, Tosun F, Rüedi P (2006) Antitrypanosomal and antileishmanial activities of flavonoids and their analogues: in vitro, in vivo, structure-activity relationship, and quantitative structure-activity relationship studies. Antimicrob Agents Chemother 50:1352-1364

26. Rivera-Chávez J, González-Andrade M, del Carmen González M, Glenn AE, Mata R (2013) Thielavins A, J and K: $\alpha$-Glucosidase inhibitors from MEXU 27095, an endophytic fungus from Hintonia latiflora. Phytochemistry 94:198-205

27. Calder PC, Geddes R (1989) Acarbose is a competitive inhibitor of mammalian lysosomal acid $\alpha$-D-glucosidases. Carbohydr Res 191:71-78

28. Martínez-Luis S, Gómez JF, Spadafora C, Guzmán HM, Gutiérrez M (2012) Antitrypanosomal alkaloids from the marine bacterium Bacillus pumilus. Molecules 17:11146-11155

29. Almanza A, Coronado L, Tayler N, Herrera L, Spadafora C (2011) Automated Synchronization of P. falciparum using a Temperature Cycling Incubator (TCI). Curr Trends Biotechnol Pharm 5:1130-1133 
30. Buckner FS, Verlinde CL, La Flamme AC, Van Voorhis WC (1996) Efficient technique for screening drugs for activity against Trypanosoma cruzi using parasites expressing $\beta$-galactosidase. Antimicrob Agents Chemother 40:2592-2597

31. Torres-Mendoza D, Ureña-Gonzalez LD, Ortega-Barria E, Capson TL, Cubilla-Rios L (2003) Five New Cassane Diterpenes from Myrospermum frutescens with activity against Trypanosoma cruzi. J Nat Prod 66:421-428

32. Chan HH, Sun HD, Reddy MV, Wu TS (2010) Potent $\alpha$-glucosidase inhibitors from the roots of Panax japonicus C. Phytochemistry 71:1360-1364

33. Copeland RA (2000) Enzymes: a practical introduction to structure, mechanisms and data analysis. Wiley-VCH, New York

34. Spartan 10 for Windows, Wavefunction Inc, Irvine, CA
35. Ren L, Qin X, Cao X, Wang L, Bai F, Bai G, Shen Y (2011) Structural insight into substrate specificity of human intestinal maltase-glucoamylase. Protein Cell 2:827-836

36. Berman HM, Westbrook J, Feng Z, Gilliland G, Bhat TN, Weissig H, Shindyalov IN, Bourne PE (2000) The protein data bank. Nucleic Acids Res 28:235-242

37. Thomsen R, Christensen MH (2006) MolDock: a new technique for highaccuracy molecular docking. J Med Chem 49:3315-3321

\section{Publish with ChemistryCentral and every scientist can read your work free of charge}

"Open access provides opportunities to our colleagues in other parts of the globe, by allowing anyone to view the content free of charge."

W. Jeffery Hurst, The Hershey Company.

- available free of charge to the entire scientific community

- peer reviewed and published immediately upon acceptance

- cited in PubMed and archived on PubMed Central

- yours - you keep the copyright

Submit your manuscript here:

http://www.chemistrycentral.com/manuscript/ 